\title{
THE EFFECTS OF ROW SPACING AND PLANT DENSITY ON YIELD AND YIELD COMPONENTS OF PEANUT GROWN AS A DOUBLE CROP IN MEDITERRANEAN ENVIRONMENT IN TURKEY
}

\author{
Bihter ONAT ${ }^{l}$, Halil BAKAL $L^{2}$, Leyla GULLUOGLU ${ }^{2}$, Halis ARIOGLU ${ }^{2 *}$ \\ ${ }^{1}$ Cukurova University, Vocational School of Kozan, Adana, TURKEY \\ ${ }^{2}$ Cukurova University, Faculty of Agriculture, Dep. of Field Crop, Adana, TURKEY \\ *Corresponding author: halis@cu.edu.tr
}

Received: 28.12 .2016

\begin{abstract}
This study was conducted at the Cukurova University research farm as a double crop in 2013 and 2014 in Adana, Turkey. The objective of this study was to determine the effect of row distance and plant density on yield and yield components of peanut(Arachis hypogaea $L_{\text {.) }}$ grown as a double crop. The experimental design was a split plot design with three replications. The Halisbey (Virginia type) variety was used as a plant material in this research. The row spacing was arranged 70 and $75 \mathrm{~cm}$, and intra-row spacing of 5,10,15,20 and $25 \mathrm{~cm}$ was arranged for different plants population. According to a two-year average, the highest pods weight $\left(97.57 \mathrm{~g} \mathrm{plant}^{-1}\right.$ and $\left.94.83 \mathrm{~g} \mathrm{plant}^{-1}\right)$ and pod number $\left(96.4\right.$ pods plant ${ }^{-1}$ and 93.5 pods plant $\left.^{-1}\right)$ per plant was obtained from $70 \times 25 \mathrm{~cm}$ and $75 \times 25 \mathrm{~cm}$ planting density, respectively. Pod number and pod weight per plant was increased when the plant density was decreased. Pod yield per hectare was increased when the plant density was increased. The highest pod yield $\left(7511.9 \mathrm{~kg} \mathrm{ha}^{-1}\right)$ was obtained from $75 \times 10 \mathrm{~cm}$ and the lowest $(5171$ $\mathrm{kg} \mathrm{ha}^{-1}$ ) from $75 \times 25$ planting density according to a two-year average. As a result; optimum planting density was found $75 \times 10 \mathrm{~cm}$ for Virginia market type varieties in double crop peanut production.
\end{abstract}

Keywords: Double crop, peanut, plant density, pod yield, row spacing

\section{INTRODUCTION}

Peanut is one of the world's most popular crops cultivated in tropical and sub-tropical regions. Because of its high protein, oil, fatty acid, carbohydrates, vitamins and minerals contents, peanut has high commercial and nutritional value. It contains $45-55 \%$ oil, $20-25 \%$ protein, $16-18 \%$ carbohydrate and 5\% minerals (Gulluoglu, 2011; Gulluoglu et al., 2016a).

The world annual peanut production is around 45.6 million tons in 24.4 million hectares of production area (Anonymous, 2015). Peanut cultivation has great potential in Turkey, in Mediterranean region. 147.537 tons of peanuts cultivated in Turkey in 2015 and $90 \%$ of this amount grown in Mediterranean region mainly in Adana and Osmaniye (Anonymous, 2016).

Egli (1988), reported that to define the relationship between row spacing, plant densities and yield; two approaches are used commonly. First, if the plant produces enough leaf area to maximize isolation interception during reproductive growth, maximum yield can be obtained. Secondly, equidistant row spacing between plants will provide maximum yield since it will minimize inter plant competition.
Plant density is defined as the number of main stems within a unit area of land. Donald (1963) indicated that as the number of plants per unit area increased, competition for growth resources such as nutrients, water and light also increased. Crop yield is determined by the efficiency with which plant population uses available environmental resources for growth. Peanut (Arachis hypogaea L.) cultivars vary in the duration of plant growth and maturity, growth habits, and branching patterns that range from the erect and sequential types of Arachis hypogaea subsp. fastigiata to the semi-erect and runner types with alternated branching in Arachis hypogaea subsp. hypogaea. The manipulation of row spacing dimensions, plant populations and the overall special arrangement of crop plants in a field has been the subject of considerable discussion among farmers and agronomists for many years. Plant density is important factor for growth and pod production rate, pod and kernel yield in peanut (Silvertooth, 1999).

The response of peanut to plant density has been investigated in many areas of the world. Kvien et al. (1987) reported that increasing population from 30.000 to 240.000 plants $^{-1} \mathrm{in}^{-1}$ increased yield from 5290 to $6840 \mathrm{~kg}$ $\mathrm{ha}^{-1}$. Gardner and Auma (1989), pointed out that pod yield in Africa was the highest when plant population density 
ranged from 98.000-274.000 plants ha ${ }^{-1}$ whereas, Phillips and Norman (1962) cultivars observed only a slight response to population density higher than 74.100 plants ha $^{-1}$. Wrihgt and Bell (1992), also studied the effect of plant population on peanut. They suggested that in groundnut by reduce plant density pod yields were increased.

According to Madkour et al. (1992), effects of row spacing on seed and pod yields was significant and $50 \mathrm{~cm}$ row spacing showed higher yields, compared to $60 \mathrm{~cm}$ row spacing. Likewise, Papastylianou (1995), suggested that maximum yield was obtained with 7-8 plantsm $^{-2}$ and yield gradually increased to maximum with 11-14 plantsm ${ }^{-2}$. Yield was unaffected by further increasing plant density while at lower than $7-8$ plantsm $^{-2}$ it was significantly reduced. Rasekh et al. (2010), pointed out that pod yield of peanut was increased with increasing of plant density from 3.0-8.3 plants $^{-2}$ but increasing plant density to 14.8 plants $\mathrm{m}^{-2}$ pod yield decreased.

Plant populations, cultivar, cultural practice and other environmental factors, interact with each other determine yield. The results have shown that groundnut in close row patterns has yield about $14 \%$ more than the conventional spacing (Schilling and Gibbons, 2002). Jaaffar and Gardner (1988), indicated that optimum plant population density in peanut varies between environments, cultivars and plant arrangements.

High plant populations provide a way to optimize pod yield in short-season production systems. Several researchers have reported that peanut pod yield was higher in high plant density than grown in low plant density (Lanier et al., 2004; Sorensen et al., 2005; Ahmad et al., 2007; Rasekh et al., 2010; Konlan et al., 2013).

Peanut is grown as a main $(60 \%)$ and double (40\%) crop in Mediterranean region in Turkey. Usually single row planting pattern and 95.000-100.000 plant ha ${ }^{-1}$ (70x15 $\mathrm{cm})$ plant density were applying in main crop peanut production in Turkey. At the double crop conditions, growing period is shorter than main crop conditions. When the plant density increases, the plants produce fewer pods and most of them are mature. For this reason, the plant population density is a very important in double crop peanut production.

The purpose of this study was to determined, how pod yield and yield components of peanut are affected by row spacing and plant spacing of double crop peanut production in Mediterranean region, Turkey.

\section{MATERIALS AND METHODS}

\section{Materials}

Field experiments were conducted at Field Crops Department Research Area $\left(41^{\circ} 04^{\prime} \mathrm{N}, 36^{\circ} 71^{\prime} \mathrm{E}\right.$, and $\left.36 \mathrm{~m}\right)$, during the 2013 and 2014 as double crop after wheat harvesting. A commercial cultivar Halisbey was used as plant material in this study. Halisbey is a member of the Virginia group and has a semi-erect development form. It has a growing period of approximately 130-140 days.

The soil texture of the expremental area was clay loam. The soil tests indicated that $\mathrm{pH}$ of 7.7 with high concentrations of $\mathrm{K}_{2} \mathrm{O}$ and low concentrations of $\mathrm{P}_{2} \mathrm{O}_{5}$. In addition, the organic matter and nitrogen content of the soil were very low. The lime content was $22.3 \%$ in the upper layers with increased levels in lower layers.

Mediterranean climate prevails in this region. Wintersare mild and rainy, whereas summers are dry and warm. The average monthly air temperature during the research period June-November) was 17.2 to $28.6^{\circ} \mathrm{C}$ in 2013 and 14.7 to $29.1^{\circ} \mathrm{C}$ in 2014 . The total rainfall was $71.9 \mathrm{~mm}$ and $205.4 \mathrm{~mm}$ during the growing periods in 2013 and 2014, respectively. The average relative humidity was ranged from 47.9 to $69.0 \%$ in 2013 and 62.9 to $72.6 \%$ in 2014 . The differences between the years and long term for the climatic data were not significant (Table $1)$.

Table 1. The average monthly temperature, monthly precipitation and relative humidity during the 2013, 2014 and long term (19502015) growing seasons in Adana, Turkey (Anonymous, 2016).

\begin{tabular}{lccccccccc}
\hline \multirow{2}{*}{ Months } & \multicolumn{3}{c}{ Avg. temperature $\left({ }^{\circ} \mathbf{C}\right)$} & \multicolumn{3}{c}{ Precipitation $(\mathbf{m m})$} & \multicolumn{3}{c}{ Relative humidity $(\%)$} \\
& $\mathbf{2 0 1 3}$ & $\mathbf{2 0 1 4}$ & $\mathbf{L T} *$ & $\mathbf{2 0 1 3}$ & $\mathbf{2 0 1 4}$ & $\mathbf{L T}$ & $\mathbf{2 0 1 3}$ & $\mathbf{2 0 1 4}$ & $\mathbf{L T}$ \\
\hline June & 25.3 & 24.8 & 25.6 & 0.3 & 1.7 & 19.8 & 65.7 & 70.5 & 68.0 \\
July & 28.2 & 28.2 & 28.1 & 0.0 & 0.3 & 7.0 & 65.2 & 72.6 & 71.6 \\
August & 28.6 & 29.1 & 28.5 & 0.0 & 0.3 & 5.3 & 69.0 & 70.3 & 71.0 \\
September & 25.3 & 25.9 & 25.9 & 15.0 & 80.4 & 17.6 & 63.1 & 64.1 & 65.4 \\
October & 19.5 & 21.0 & 21.3 & 16.5 & 67.8 & 40.6 & 47.9 & 62.9 & 61.6 \\
November & 17.2 & 14.7 & 15.5 & 40.1 & 54.9 & 72.7 & 50.0 & 64.3 & 60.3 \\
\hline * & & & & & & & & &
\end{tabular}

*LT: Long term

\section{Method}

The field experiments were laid out in Split Plot Design with three replications. The experimental sites were cultivated deeply by disked-harrowed. Before sowing (according to the results of soil analysis), $250 \mathrm{~kg} \mathrm{ha}^{-1}$ of Diamonium phosphate $\left(45 \mathrm{~kg} \mathrm{ha}^{-1} \mathrm{~N}, 115 \mathrm{~kg} \mathrm{ha}^{-1} \mathrm{P}_{2} \mathrm{O}_{5}\right)$ was applied. Mineral fertilizer rates were determined based on the nutritional requirements of peanut and soil nutrient availability. Amonium nitrate $(33 \% \mathrm{~N})$ at the rate of $400 \mathrm{~kg} \mathrm{ha}^{-1}$ was applied as a two times before first and third irrigation (flowering and pod formation). In the experiment; 10 different plant densities which consist of two row distances $(70$ and $75 \mathrm{~cm})$ and five different plant 
spaces $(5,10,15,20$ and $25 \mathrm{~cm}$ ) were established (Table 2).

Table 2. Average plant population density and seeding rate for different row distances and plant spaces

\begin{tabular}{cccc}
\hline $\begin{array}{c}\text { Row } \\
\text { distance } \\
(\mathbf{c m})\end{array}$ & $\begin{array}{c}\text { Plant } \\
\text { spaces } \\
(\mathbf{c m})\end{array}$ & $\begin{array}{c}\text { Plant } \\
\text { density } \\
\left(\text { plant ha }^{-1}\right)\end{array}$ & $\begin{array}{c}\text { Seeding } \\
\text { rate } \\
\left(\text { kg ha }^{-1}\right)\end{array}$ \\
\hline & 5 & 285.000 & 411.7 \\
$70 \mathrm{~cm}$ & 10 & 142.000 & 205.1 \\
& 15 & 95.000 & 137.2 \\
& 20 & 71.000 & 102.6 \\
& 25 & 57.000 & 82.3 \\
\hline $75 \mathrm{~cm}$ & 5 & 266.000 & 384.2 \\
& 10 & 133.000 & 192.1 \\
& 15 & 88.000 & 127.1 \\
& 20 & 66.000 & 95.3 \\
& 25 & 53.000 & 76.6 \\
\hline
\end{tabular}

The seeds were planted by hand in the second week of June ( $15^{\text {th }}$ of June) in each year of the study. The peanut seeds were treated with fungicide (Thiram) before sowing against to Aspergillus Crown Rot (Aspergillius niger van Tieghem). During the growing period, other standard cultural practices (weed control, irrigation, pest and disease control) were applied at proper time intervals.

The plants were harvested by hand when the $60 \%$ of the pods are matured in both growing seasons $\left(10^{\text {th }}\right.$ of November). Pod number and pod weight per plant and fancy pod (first quality pod) number percentage was measured from 20 plants randomly selected from each plot at the harvesting time. Yield data per plot was measured in a similar way from all remaining plants excluding the very end on each side of the two central rows. 100 seed weight and shelling percentage data were obtained after harvesting (Gulluoglu et al., 2016b). Kernel yield was calculated as the ration of pod yield $\mathrm{x}$ shelling percentage (Rasekh et al., 2010).

Determination of oil percentage; oil was extracted from peanut seeds using (Soxhlet), and oil percentage was estimated according to Association of Official Analytical Chemists (AOAC, 2010). Determination of Protein percentage; Nitrogen percentage in seeds was estimated using (Micro-Kjeldahl) method according to Association of Official Analytical Chemists (AOAC, 2010). Protein percentage was calculated according to the following equation; Protein percentage $=$ Nitrogen percentage $(\mathrm{N} \%)$ x 6.25 .

The data obtained were statistically analyzed by the computing Jump 8.1.0 statistical software in accord with the Split Plot Design. The means of the treatment were compared by using the LSD as described.

\section{RESULTS AND DISCUSSION}

\section{Pod number and pod weight per plant}

The data regarding to pod number per plant and pod weight per plant at different row distance and plant spaces in double crop peanut production has been presented in Table 3.

Table 3. The effect of row distances and plant spaces on pod weight $\left(\mathrm{g} \mathrm{plant}^{-1}\right)$ and pod number (pod plant $\left.{ }^{-1}\right)$ of per plant in double crop peanut production in 2013, 2014 and two years average in Adana.

\begin{tabular}{|c|c|c|c|c|c|c|}
\hline \multirow{2}{*}{ Treatments } & \multicolumn{3}{|c|}{ Pod number (pod plant $\left.{ }^{-1}\right)$} & \multicolumn{3}{|c|}{ Pod weight (g plant $\left.{ }^{-1}\right)$} \\
\hline & 2013 & 2014 & Average & 2013 & 2014 & Average \\
\hline \multicolumn{7}{|l|}{ Row distances (A) } \\
\hline $70 \mathrm{~cm}$ & 62.2 & 65.8 & 64.0 & 63.2 & 67.5 & 65.3 \\
\hline $75 \mathrm{~cm}$ & 65.1 & 68.9 & 67.0 & 66.4 & 68.4 & 67.4 \\
\hline \multicolumn{7}{|l|}{ Plant spaces (B) } \\
\hline $5 \mathrm{~cm}$ & 25.8 & 27.6 & 26.7 & 23.6 & 25.3 & 24.5 \\
\hline $10 \mathrm{~cm}$ & 48.7 & 52.6 & 50.6 & 52.8 & 56.1 & 54.5 \\
\hline $15 \mathrm{~cm}$ & 69.4 & 74.0 & 71.7 & 70.5 & 74.2 & 72.3 \\
\hline $20 \mathrm{~cm}$ & 81.2 & 85.7 & 83.5 & 82.0 & 86.6 & 84.3 \\
\hline $25 \mathrm{~cm}$ & 93.1 & 96.9 & 95.0 & 95.0 & 97.5 & 96.2 \\
\hline $\operatorname{LSD}\left(\% 5_{\mathrm{A}}\right)$ & 1.10 & 0.98 & 0.48 & 1.17 & NS & 0.86 \\
\hline $\operatorname{LSD}\left(\% 5_{\mathrm{B}}\right)$ & 2.66 & 1.73 & 1.52 & 2.83 & 2.16 & 1.71 \\
\hline $\operatorname{LSD}\left(\% 5_{\mathrm{AxB}}\right)$ & NS & NS & 2.15 & NS & 3.06 & 2.42 \\
\hline
\end{tabular}

Statistical analysis for row distance and plant spaces showed significant effect on pod number per plant. Pod number per plant values varied between 62.2-65.1 pods plant $^{-1}$ in 2013, between 65.8-68.9 pods plant ${ }^{-1}$ in 2014 and 64.0-67.0 pods plant ${ }^{-1}$ in a two year average. According to a two-year average, increasing the row distance from $70 \mathrm{~cm}$ to $75 \mathrm{~cm}$, pod number per plant was increased from 64.0 to 67.0 pods plant ${ }^{-1}$. Planting density is important factor for growth and pod production in peanut. The highest pod number per plant was obtained from $75 \mathrm{~cm}$ row spacing due to less competition among the plants to get enough space for their growth and development. Donald (1963) indicated that as the number of plants per unit area increased, competition for growth resources such as nutrients, water and light also increased. These results are in agreement with the findings of Madkour et al. (1992), Patil et al. (2007) and Awal and Aktar (2015). 
It can be seen in Table 3, the differences between the plant spaces were significant for pod number per plant in 2013, 2014 and two years average. Pod number per plant varied from 25.8 to 93.1 pods plant ${ }^{-1}$ in 2013 , from 27.6 to 96.9 pods plant $^{-1}$ in 2014 and from 26.7 to 95.0 pods plant $^{-}$ ${ }^{1}$ in a two-year average (Table 3 ). By increasing intra-row spacing, the number of pods per plant was increased in both years. The highest pod number per plant was obtained when the sowing was done at $25 \mathrm{~cm}$ inter row spacing. Peanut produced more pods per plant with increasing plant spaces because of decreasing plant density leads more peanut pegs penetration of each plant to soil.

Giayetto et al. (1998) reported that the number of branching per plant was reduced with the increase of plant density. As plant density was decreased in per unit area, pod number per plant was increased. At low plant density, existing plants developed more branches and pegs because of reduced in competition. Donald (1963) reported that as the number of plants per unit area increased competition for growth resources such as nutrients, water and light also increased. Similar results were reported by others researches (Wright and Bell, 1992; Sternitzke et al., 2000; Ahmad et al., 2007 and Konlan et al., 2013)

According to a two-year average, interaction between the row distance and plant space for the pod number per plant was significant and revealed that caused competition decrease among the plants, also increased the pod number of plant. The greatest number of pods per plant value was recorded as $75 \times 25 \mathrm{~cm}\left(53.000\right.$ plants $\left.\mathrm{ha}^{-1}\right)$ and $70 \times 25 \mathrm{~cm}$ (57.000 plants $\mathrm{ha}^{-1}$. Figure 1 shows that decreasing the plant density from 285.000 plants ha $^{-1}$ to 53.000 plants ha ${ }^{1}$, significantly increased pod number per plant. At low density, existing plants developed more pegs and pods because of reduced in competition. The number of pods tended to decrease with increased population density.

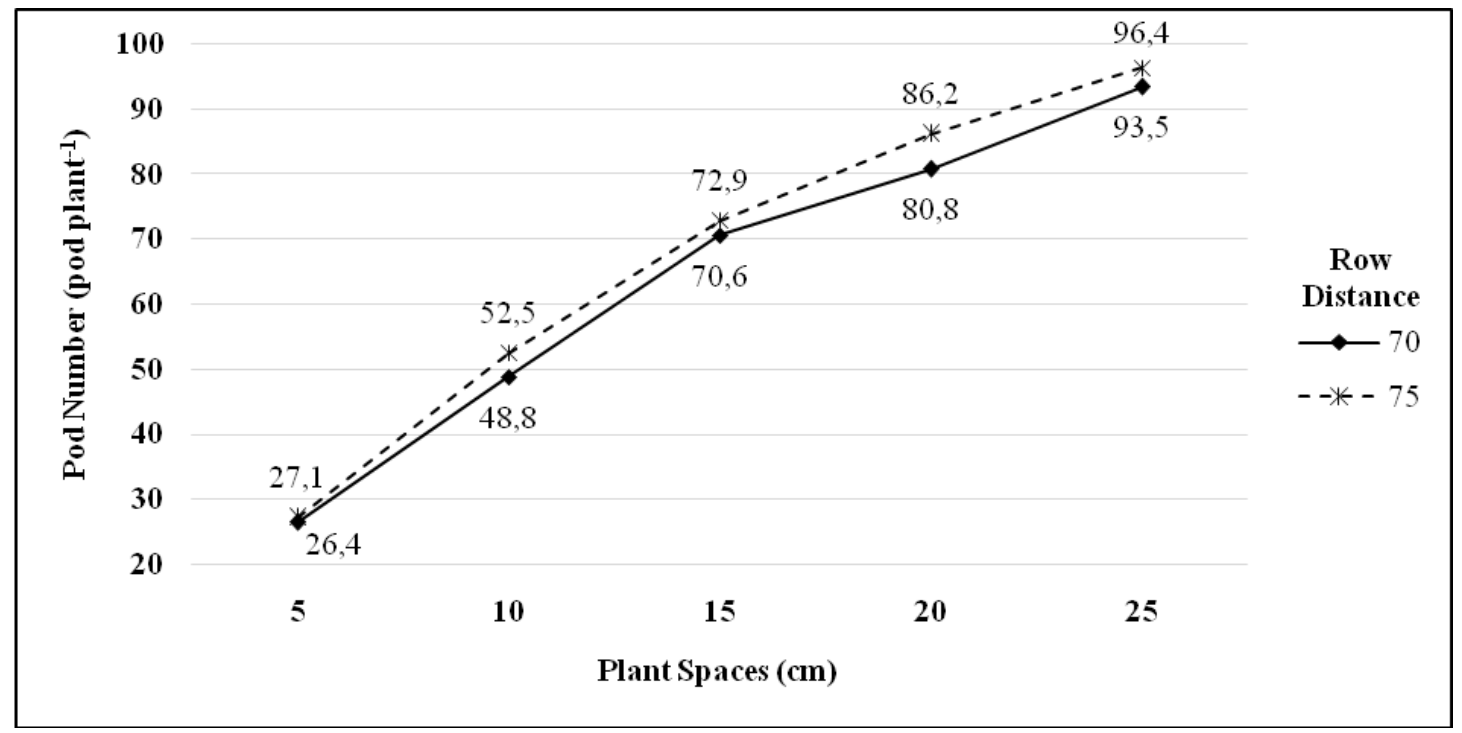

Figure 1.Interaction betweenrow distance and plant spaces for pod number per plant

The variability of row distances and plant spaces had statistically significant effects on pod weight per plant in a two-year average (Table 3 ). Increasing both row distance and plant spaces increased pod weight per plant. According to the data 2013 and 2014 years average; increasing row distance from $70 \mathrm{~cm}$ to $75 \mathrm{~cm}$, significantly increased pod weight per plant from $65.3 \mathrm{~g}$ plant ${ }^{-1}$ to $67.4 \mathrm{~g} \mathrm{plant}^{-1}$, similar results were obtained by increasing plant spaces from $5 \mathrm{~cm}$ to $25 \mathrm{~cm}$, increased pod weight per plant from $24.5 \mathrm{~g} \mathrm{plant}^{-1}$ to $96.2 \mathrm{~g} \mathrm{plant}^{-1}$. The reason of pod weight increase, the pod number per plant was increased when the plant density decreased. These results are in agreement with the findings of Sorensen et al. (2005), Konlan et al. (2013) and Dapaah et al. (2014).

The average pod weight per plant in interaction effects between row distance with plant spaces was also significant and revealed that caused competition decrease among the plants, also increased the pod weight per plant (Figure 2). 


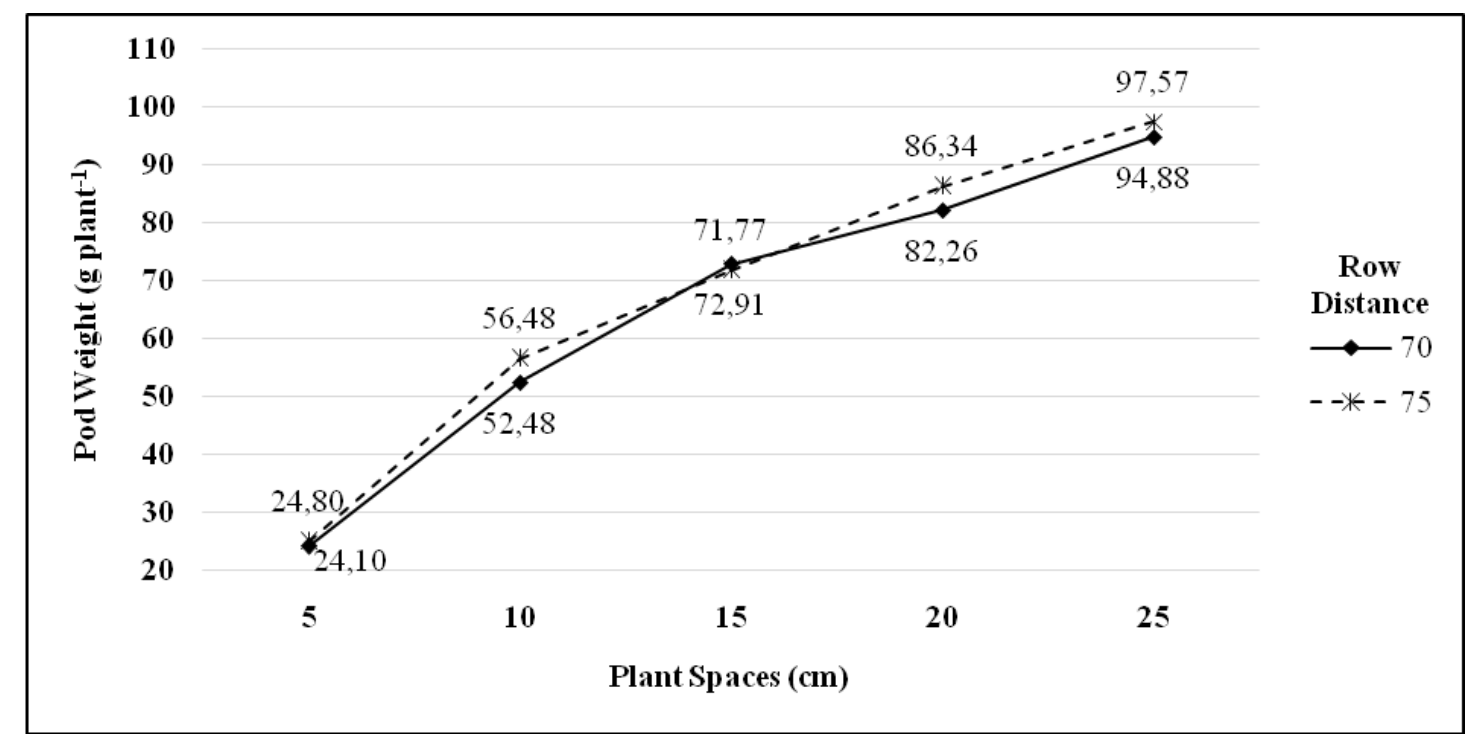

Figure 2. Interaction between row distance and plant spaces for pod weight per plant.

The greatest pod weight per plant was recorded as $75 \times 25 \mathrm{~cm}\left(53.000\right.$ plants $\left.^{-1} \mathrm{a}^{-1}\right)$ and $70 \times 25$ (57.000 plants $\mathrm{ha}^{-1}$ ) whereas the lowest pod weight per plant was recorded as $70 \times 5 \mathrm{~cm}\left(285.000\right.$ plants $\left.\mathrm{ha}^{-1}\right)$ and $75 \times 5 \mathrm{~cm}$ $\left(266.000\right.$ plants $\left.^{-1}{ }^{-1}\right)$. Figure 2 shows that decreasing the plant density significantly increased pod weight per plant considerable. These could potentially be explained by decreasing plant density provides higher photosynthesis per plant. These findings are supported by Shiwlong and Tehming, (1996) and Sternitzke et al. (2000).

\section{The shelling percentage and hundred seed weight}

The means of shelling percentage and hundred seed weights obtained from the row distance and plant spaces presented in Table 4.

Table 4. The effect of row distances and plant spaces on shelling percentage (\%) and 100 seed weight (g) in double crop peanut production in 2013, 2014 and two years average in Adana.

\begin{tabular}{lcccccc}
\hline \multirow{2}{*}{ Treatments } & \multicolumn{3}{c}{ Shelling percentage (\%) } & \multicolumn{3}{c}{ 100 Seed weight } \\
& $\mathbf{2 0 1 3}$ & $\mathbf{2 0 1 4}$ & Average & $\mathbf{2 0 1 3}$ & $\mathbf{2 0 1 4}$ & Average \\
\hline Row distances (A) & & & & & & \\
$70 \mathrm{~cm}$ & 64.6 & 65.2 & 64.9 & 125.9 & 129.4 & 127.7 \\
$75 \mathrm{~cm}$ & 65.7 & 64.6 & 65.2 & 136.4 & 129.0 & 133.1 \\
\hline Plant spaces (B) & & & & & & \\
$5 \mathrm{~cm}$ & 64.6 & 63.9 & 64.2 & 118.1 & 124.7 & 121.4 \\
$10 \mathrm{~cm}$ & 65.6 & 64.5 & 65.1 & 125.8 & 127.6 & 126.7 \\
$15 \mathrm{~cm}$ & 65.7 & 65.9 & 65.8 & 132.6 & 128.9 & 130.7 \\
$20 \mathrm{~cm}$ & 65.2 & 65.5 & 65.3 & 137.5 & 132.0 & 134.7 \\
$25 \mathrm{~cm}$ & 64.8 & 64.7 & 64.8 & 141.9 & 135.1 & 138.5 \\
\hline LSD $\left(\% 5_{\mathrm{A}}\right)$ & $\mathrm{NS}$ & $\mathrm{NS}$ & $\mathrm{NS}$ & $\mathrm{NS}$ & $\mathrm{NS}$ & $\mathrm{NS}$ \\
LSD $\left(\% 5_{\mathrm{B}}\right)$ & $\mathrm{NS}$ & $\mathrm{NS}$ & $\mathrm{NS}$ & 11.93 & 4.50 & 6.12 \\
LSD $\left(\% 5_{\mathrm{AxB}}\right)$ & $\mathrm{NS}$ & $\mathrm{NS}$ & $\mathrm{NS}$ & $\mathrm{NS}$ & $\mathrm{NS}$ & $\mathrm{NS}$ \\
\hline
\end{tabular}

As can be observed in Table 4, the shelling percentage was not affected by row distance and plant spaces. Referring to the means of both experiment years; the shelling percentage values were in the range of $64.9 \%$ to $65.2 \%$ with various row distances and $64.2 \%$ to $65.8 \%$ in different plant spaces. Hence it could easily be observed that plant density has no effect on shelling percentage. Similar results have also been reported by Nandania (1993). Interaction of row distance and plant spaces on shelling percentage was not found statistically significant.

There was not significant difference between the row distance for 100 seed weight value in 2013, 2014 and in a two-year average (Table 4). 100 seed weight values varied between 125.9-136.4 $\mathrm{g}$ in 2013, between 129.0-129.4 $\mathrm{g}$ in 2014 and between 127.7-133.1 g in a two-year average. By increasing row distance from $70 \mathrm{~cm}$ to $75 \mathrm{~cm}$, the 100 seed weight was increased in both years (Table 4). According to a two-year average, the highest 100 seed weight $(133.1 \mathrm{~g})$ was obtained from $75 \mathrm{~cm}$ row distance.

It can be seen in Table 4, the differences between the plant spaces were significant for seed weight in both years and two years average. The $25 \mathrm{~cm}$ plant spacing produced the largest seeds $(138.5 \mathrm{~g} / 100$ seed weight) whereas $5 \mathrm{~cm}$ plant spacing produced the smallest seeds (121.4 g/100 
seed weight). Spacing differences regarding 100 seed weight might be due to the competition for light, water and other essential requirements among the plants. Ahmad et al. (2007) and Konlan et al. (2013) reported that 100 seed weight decreased with increasing plant density in peanut. According to a two-year average, interaction between the row distance and plant space for hundred seed weight was not statistically significant.

\section{Protein and oil content}

The data belonging to protein and oil content at different row distance and plant spaces in double crop peanut production has been presented in Table 5 .

Table 5. The effect of row distances and plant spaces on protein and oil content (\%) in double crop peanut production in 2013,2014 and two years average in Adana

\begin{tabular}{|c|c|c|c|c|c|c|}
\hline \multirow{2}{*}{ Treatments } & \multicolumn{3}{|c|}{ Protein content (\%) } & \multicolumn{3}{|c|}{ Oil content (\%) } \\
\hline & 2013 & 2014 & Average & 2013 & 2014 & Average \\
\hline \multicolumn{7}{|c|}{ Row distances (A) } \\
\hline $70 \mathrm{~cm}$ & 23.9 & 22.4 & 23.1 & 45.9 & 47.3 & 46.6 \\
\hline $75 \mathrm{~cm}$ & 23.8 & 22.9 & 23.3 & 46.3 & 46.9 & 46.6 \\
\hline \multicolumn{7}{|l|}{ Plant spaces (B) } \\
\hline $5 \mathrm{~cm}$ & 24.4 & 23.5 & 24.0 & 45.6 & 45.4 & 45.5 \\
\hline $10 \mathrm{~cm}$ & 24.1 & 23.0 & 23.6 & 45.9 & 46.4 & 46.1 \\
\hline $15 \mathrm{~cm}$ & 23.7 & 22.5 & 23.1 & 46.1 & 47.2 & 46.6 \\
\hline $20 \mathrm{~cm}$ & 23.5 & 22.2 & 22.9 & 46.4 & 47.9 & 47.1 \\
\hline $25 \mathrm{~cm}$ & 23.5 & 21.9 & 22.7 & 46.6 & 48.5 & 47.5 \\
\hline $\operatorname{LSD}\left(\% 5_{\mathrm{A}}\right)$ & NS & NS & NS & 0.30 & NS & NS \\
\hline $\operatorname{LSD}\left(\% 5_{\mathrm{B}}\right)$ & 0.63 & 0.64 & 0.43 & 0.35 & 1.08 & 0.54 \\
\hline $\operatorname{LSD}\left(\% 5_{\mathrm{AxB}}\right)$ & NS & NS & NS & NS & NS & NS \\
\hline
\end{tabular}

There was not statistically significant difference between the row distances for oil contend value in 2013, 2014 and in a two-year average (Table5). According to a two-year average, the protein content was $23.1 \%$ in $70 \mathrm{~cm}$ row distance and $23.3 \%$ in $75 \mathrm{~cm}$ row distance.

Row distance could not affect protein content of peanut, whereas plant spaces affected it significantly. The highest protein content was obtained in $5 \mathrm{~cm}$ plant space $(24.0 \%)$, and the lowest obtained in $25 \mathrm{~cm}(22.7 \%)$ in a two year average. Interaction of row distance and plant spaces in this case was not found significant in both years (Table 5).

The differences between the row distances were statistically significant for oil content in 2013 and 2014, whereas in a two year average was not significant. The oil content values varied between $45.9-46.3 \%$ in 2013 and $46.9-47.3 \%$ in 2014 at different row spacing. The oil content was found $46.6 \%$ in a two years average. This finding shows that oil content of peanut was not affected by row distance (Table 5).

It can be seen in Table 5, the differences between the plant spaces were significant for oil content in both years and in a two year average. The oil content values varied between $45.6-46.6 \%$ in $2013,45.4-48.5 \%$ in 2014 and $45.5-47.5 \%$ in a two year average. The oil content was decreased when the plant space was reduced. The highest oil content $(46.6 \%$ and $48.5 \%)$ was obtained when the plant space was $25 \mathrm{~cm}$ in both years. The similar result was found by the Kadiroglu (2012) and Gulluoglu et al. (2016c).
Interaction of row distance and plant spaces for the oil content was not significant in both years. The findings are in agreement with the findings reported by Kaushik and Chaubey (2000).

\section{Pod and kernel yield}

The data belonging to pod and kernel yield per hectare at different row distance and plant spaces in double crop peanut production has been presented in Table 6 .

It can be seen in Table 6, the differences between the row distances were statistically significant in 2013 and two years average, whereas there was no statistically significant difference in 2014. The pod yield per hectare varied between $6145.2-6257.7 \mathrm{~kg} \mathrm{ha}^{-1}$ in 2013 , 6372.2$6718.6 \mathrm{~kg} \mathrm{ha}^{-1}$ in 2014 and $6258.7-6488.2 \mathrm{~kg} \mathrm{ha}^{-1}$ in a two year average. Increasing the row distance from $70 \mathrm{~cm}$ to $75 \mathrm{~cm}$, significantly decreased pod yield from 6488.2 $\mathrm{kg} / \mathrm{ha}$ to $6258.7 \mathrm{~kg} / \mathrm{ha}$. The yield is equal to plant number per hectare $\mathrm{x}$ pod yield per plant. In this equation, the pod yield was decreased when the plant density increased, but the plant number per hectare was increased when the plant density increased. For this reason, the pod yield per hectare was increased when the row distance decreased. Madkour et al. (1992) showed that effects of row spacing on pod yield was significant and $50 \mathrm{~cm}$ row spacing showed higher yields compared to $60 \mathrm{~cm}$ row spacing. Kaushik and Chaubey (2000) conducted a field study and found that pod yield was highest with inter-row spacing of $30 \mathrm{~cm}$ (1.86 and $2.58 \mathrm{t} / \mathrm{ha}$ in 1996 and 1997, respectively) as compared to $60 \mathrm{~cm}$ row spacing. 
Table 6. The effect of row distances and plant spaces on pod yield and kernel yield $\left(\mathrm{kg} \mathrm{ha}^{-1}\right)$ per hectare in double crop peanut production in 2013, 2014 and two years average in Adana

\begin{tabular}{|c|c|c|c|c|c|c|}
\hline \multirow{2}{*}{ Treatments } & \multicolumn{3}{|c|}{ Pod yield $\left(\mathrm{kg} \mathrm{ha}^{-1}\right)$} & \multicolumn{3}{|c|}{ Kernel yield (kg ha $\left.{ }^{-1}\right)$} \\
\hline & 2013 & 2014 & Average & 2013 & 2014 & Average \\
\hline \multicolumn{7}{|c|}{ Row distances (A) } \\
\hline $70 \mathrm{~cm}$ & 6257.7 & 6718.6 & 6488.2 & 4047.5 & 4379.0 & 4213.2 \\
\hline $75 \mathrm{~cm}$ & 6145.2 & 6372.2 & 6258.7 & 4039.9 & 4117.7 & 4078.8 \\
\hline \multicolumn{7}{|l|}{ Plant spaces (B) } \\
\hline $5 \mathrm{~cm}$ & 6511.3 & 6974.0 & 6742.6 & 4209.0 & 4452.3 & 4330.7 \\
\hline $10 \mathrm{~cm}$ & 7254.9 & 7709.1 & 7482.0 & 4758.2 & 4977.4 & 4867.8 \\
\hline $15 \mathrm{~cm}$ & 6415.6 & 6753.5 & 6584.6 & 4216.6 & 4455.7 & 4336.1 \\
\hline $20 \mathrm{~cm}$ & 5607.2 & 5930.8 & 5769.0 & 3655.4 & 3885.3 & 3770.4 \\
\hline $25 \mathrm{~cm}$ & 5218.1 & 5359.8 & 5288.9 & 3379.4 & 3471.0 & 3425.2 \\
\hline $\operatorname{LSD}\left(\% 5_{\mathrm{A}}\right)$ & 48.75 & NS & 149.29 & NS & NS & 115.97 \\
\hline $\operatorname{LSD}\left(\% 5_{\mathrm{B}}\right)$ & 246.27 & 275.30 & 177.46 & 210.46 & 235.68 & 151.80 \\
\hline $\operatorname{LSD}\left(\% 5_{\mathrm{AxB}}\right)$ & NS & NS & 250.97 & NS & NS & NS \\
\hline
\end{tabular}

Pod yield per hectare values varied between 5218.1$7254.9 \mathrm{~kg} \mathrm{ha}^{-1}$ in 2013, between $5359.8-7709.1 \mathrm{~kg} \mathrm{ha}^{-1}$ and between 5288.9-7482.0 kg ha-1 in a two year average (Table 6). The differences between the plant spaces were statistically significant in both years and two years average. According to a two year average, the highest $\left(7482.0 \mathrm{~kg} \mathrm{ha}^{-1}\right)$ pod yield was obtained when the sowing was done at the $10 \mathrm{~cm}$ plant space and the lowest $(5288.9$ $\mathrm{kg} \mathrm{ha}^{-1}$ ) pod yield was obtained plant space was $25 \mathrm{~cm}$.

Increasing the plant spaces from $5 \mathrm{~cm}$ to $25 \mathrm{~cm}$, the pod yield per plant was increased from $24.5 \mathrm{~g}$ to $96.2 \mathrm{~g}$ in a two year average (Table 3 ), whereas the plant number per hectare was increased from 57.000 plants to 285.000 plants in $70 \mathrm{~cm}$ row distance and 53.000 plants to 266.000 plants in $75 \mathrm{~cm}$ row distance (Table 2). Giayetto et al. (1998) reported that the number of branching per plant was reduced with the increase of plant density. As plant density was decreased in per unit area, pod number per plant was increased. At low plant density, existing plants developed more branches and pegs because of reduced in competition. Donald (1963) reported that as the number of plants per unit area increased competition for growth resources such as nutrients, water and light also increased. By increasing the plant spaces, the plant number per hectare was decreased whereas the pod yield per hectare was increased (Pod yield per hectare $=$ Pod weight per plant $\mathrm{x}$ plant number per hectare).These findings are supported by Sternitzke et al. (2000); Lanier et al. (2004); Sorensen et al. (2005). The average pod yield was significantly affected by the interaction between row distance and plant spaces. The highest $\left(7511.9 \mathrm{~kg} \mathrm{ha}^{-1}\right.$ and $7452.2 \mathrm{~kg} \mathrm{ha}^{-1}$ ) pod yield was recorded at $75 \times 10 \mathrm{~cm}$ (133.000 plants/ha) and 70x10 cm (142.000 plants/ha). The pod yield was increased when the plant space increased from $5 \mathrm{~cm}$ to $10 \mathrm{~cm}$, and then pod yield was started to decrease when the plant spaces increased from $10 \mathrm{~cm}$ to $25 \mathrm{~cm}$ (Figure 3).

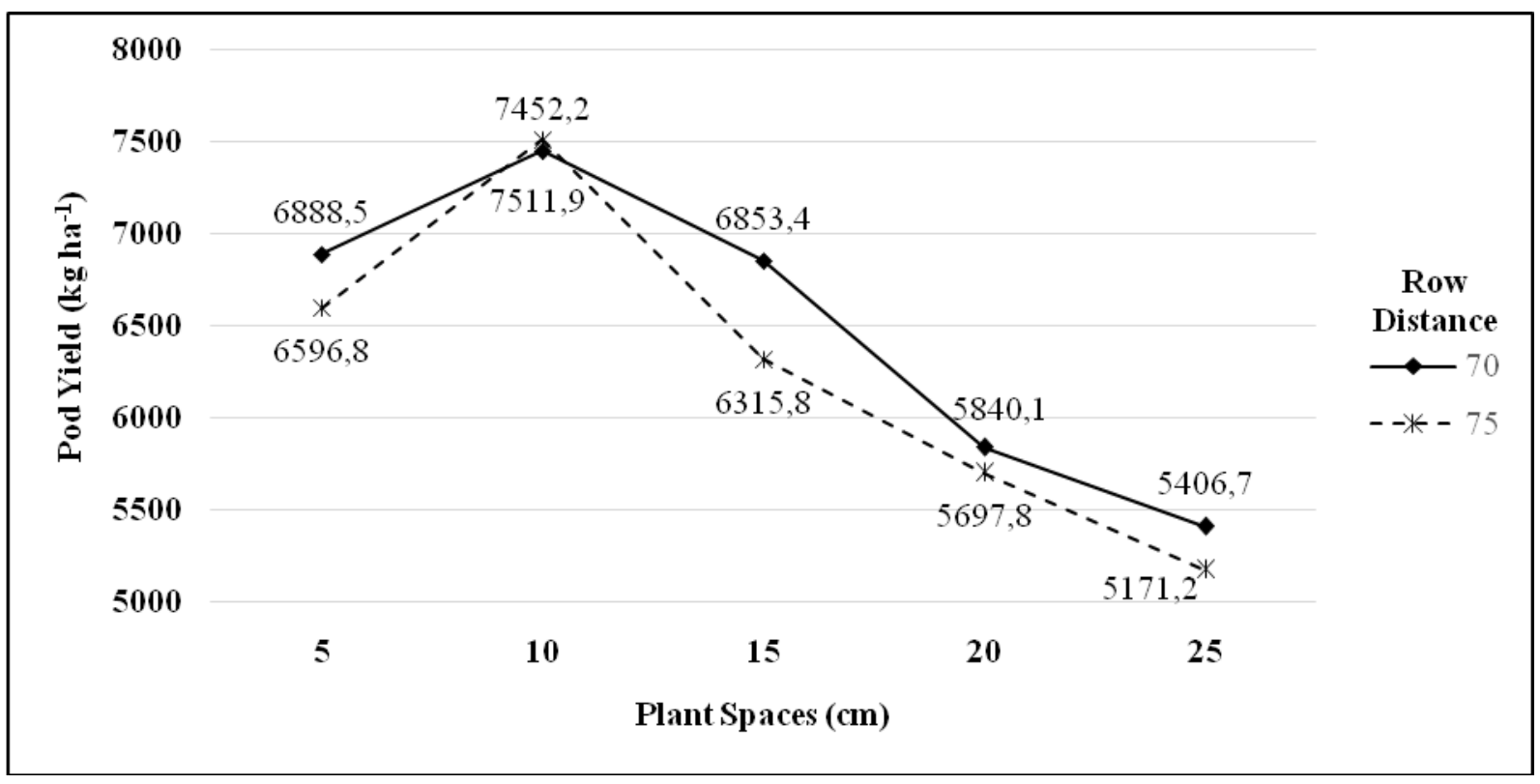

Figure 3. Interaction between row distance and plant spaces for pod yield per hectare. 
These results have showed that pod yield has increased by plant density. Roy et al. (1980) showed that seeding rates for a final stand count of between 180,000 plantsha $^{-1}$ and 300,000 plantsha $^{-1}$ produced higher pod yields than did lower or higher plant populations.Similar results were reported by other researchers Papastylianou (1995); Prasad et al. (2000) and Tavora et al. (2002) .

The kernel yield per hectare was calculated as the pod yield per hectare $\mathrm{x}$ shelling percentage (Rasekh et al. 2010). It can be seen in Table 6 , the differences between the row distances were statistically significant in a two year average, whereas there was no statistically significant difference in 2013 and 2014. According to a two year average the kernel yield values varied between $4078.8 \mathrm{~kg}$ $\mathrm{ha}^{-1}$ and $4213.2 \mathrm{~kg} \mathrm{ha}^{-1}$. The kernel yield was decreased when the row distance increased. The highest $(4213.2 \mathrm{~kg}$ $\left.\mathrm{ha}^{-1}\right)$ kernel yield was obtained in $70 \mathrm{~cm}$ row distance (Table 6).

The differences between the plant spaces were statistically significant in both years and two years average. Kernel yield data varied between 3379.4.0$4758.2 \mathrm{~kg} \mathrm{ha}^{-1}$ in 2013, 3471.0-4977.4 $\mathrm{kg} \mathrm{ha}^{-1}$ in 2014 and $3425.2-4867.8 \mathrm{~kg} \mathrm{ha}^{-1}$ in a two year average (Table 6). Kernel yield was raised with increasing plant spaces from $5 \mathrm{~cm}$ to $10 \mathrm{~cm}$ but the yield was declined when plant spaces increased further. The highest yield was obtained in $10 \mathrm{~cm}$ plant spaces as $4867.8 \mathrm{~kg} / \mathrm{ha}$ whereas the lowest was obtained in $25 \mathrm{~cm}$ as $3425.2 \mathrm{~kg} / \mathrm{ha}$. Interaction of row distance and plant spaces in this case was not found significant. These findings are supported by Giayetto et al. (1998) and Rasekh et al. (2010).

\section{Fancy pod percentage}

The fancy pod percentage is an important quality parameter in peanut production. When the fancy pod percentage increases, mean time the product of peanut quality increases. The differences between the row distance for the fancy pod percentage were not signif,cant in a both years and two years average. In this research, the fancy pod percentage was increased, while the plant space was increased. Similar results have been found by Lanier et al. (2004). The differences between the plant densities were statistically significant in both years and in a two years average (Table 7).

While the fancy pod percentage was $77.5 \%$ when the plant space at $5 \mathrm{~cm}$, the fancy pod percentage increased to $82.3 \%$ at $25 \mathrm{~cm}$ plant space in a two year average. The highest $(82.3 \%)$ fancy pod percentage value was obtained at the $25 \mathrm{~cm}$ inter-row spacing. According to a two-year average, interaction between the row distance and plant space for the fancy pod percentage was not statistically significant (Table 7).
Table 7. The effect of row distances and plant spaces on fancy pod percentage in double crop peanut production in 2013, 2014 and two years average in Adana

\begin{tabular}{cccc}
\hline \multirow{2}{*}{ Treatments } & \multicolumn{3}{c}{ Fancy pod percentage (\%) } \\
& $\mathbf{2 0 1 3}$ & $\mathbf{2 0 1 4}$ & Average \\
\hline Row distances (A) & & & \\
$70 \mathrm{~cm}$ & 77.5 & 82.9 & 80.2 \\
$75 \mathrm{~cm}$ & 78.2 & 81.6 & 79.9 \\
\hline Plant spaces (B) & & & \\
$5 \mathrm{~cm}$ & 74.2 & 80.8 & 77.5 \\
$10 \mathrm{~cm}$ & 75.0 & 83.6 & 79.3 \\
$15 \mathrm{~cm}$ & 77.3 & 82.8 & 80.1 \\
$20 \mathrm{~cm}$ & 80.0 & 82.3 & 81.1 \\
$25 \mathrm{~cm}$ & 82.8 & 81.8 & 82.3 \\
\hline LSD $\left(\% 5_{\mathrm{A}}\right)$ & $\mathrm{N} . \mathrm{S}$ & $\mathrm{NS}$ & $\mathrm{NS}$ \\
LSD $\left(\% 5_{\mathrm{B}}\right)$ & 1.78 & 1.71 & 1.19 \\
LSD $\left(\% 5_{\mathrm{AxB}}\right)$ & 2.52 & N.S. & N.S \\
\hline
\end{tabular}

\section{CONCLUSIONS}

The average pod yield was significantly affected by the row distance and plant spaces. Increasing the plant spaces from $5 \mathrm{~cm}$ to $25 \mathrm{~cm}$, the pod yield per plant was increased from $24.5 \mathrm{~g}$ to $96.2 \mathrm{~g}$ in a two year average, whereas the plant number per hectare was increased from 57.000 plants to 285.000 plants in $70 \mathrm{~cm}$ row distance and 53.000 plants to 266.000 plants in $75 \mathrm{~cm}$ row distance. The yield is equal to plant number per hectare $\mathrm{x}$ pod yield per plant. In this equation, the pod yield per plant was decreased when the plant density increased, whereas plant number per hectare was increased when the plant density increased. Planting density is one of the main factors that have an important role on growth, yield and quality of peanut. It is important to accommodate the most appropriate number of plants per unit area of land to obtain better yield. Establishment of optimum population per unit area of the field is essential to get maximum yield. For this reason, the pod yield per hectare was increased when the plant density increased.

Increasing the row distance from $70 \mathrm{~cm}$ to $75 \mathrm{~cm}$, significantly decreased pod yield from $6488.2 \mathrm{~kg} / \mathrm{ha}$ to $6258.7 \mathrm{~kg} / \mathrm{ha}$. The pod yield was increased when the plant space increased from $5 \mathrm{~cm}$ to $10 \mathrm{~cm}$, and then pod yield was started to decrease when the plant spaces increased from $10 \mathrm{~cm}$ to $25 \mathrm{~cm}$. According to a two year average, the pod yield was $7482.0 \mathrm{~kg} \mathrm{ha}^{-1}$ when the sowing was done at the $10 \mathrm{~cm}$ plant space and the yield was $5288.9 \mathrm{~kg}$ $\mathrm{ha}^{-1}$ plant space was $25 \mathrm{~cm}$.

Pod yield per hectare was increased when the plant density was increased. The highest pod yield $(7511.9 \mathrm{~kg}$ $\mathrm{ha}^{-1}$ ) was obtained from $75 \times 10 \mathrm{~cm}$ and the lowest $(5171$ $\mathrm{kg} \mathrm{ha}^{-1}$ ) from $75 \times 25$ planting density according to a twoyear average. As a result; optimum planting density was found $75 \times 10 \mathrm{~cm}$ for Virginia market type varieties in double crop peanut production in the Mediterranean region of Turkey. 


\section{LITERATURE CITED}

Ahmad, A., M. Rahim and U. Khan. 2007. Evaluation of Different Varieties, Seed Rates and Row Spacing of Groundnut, Planted Under Agro-Ecological Conditions of Malakand Division. Journal of Agronomy, 6(2):385-387

Anonymous. 2015. Crop Production Statistics. Food and Agriculture Organization of the United Nations,Rome, Italy (http://www.fao.org/crop/ statistics).

Anonymous, 2016. The Meteorological Data for Adana.The Turkish State Meteorological Service Adana Regional Directorship, 2013, 2014 and long term.

AOCS. 1989. Official and Recommended Methods. American Oil Chemists' Society Press. Champaing, IL, USA

Awal, M.A, L. Aktar. 2015. Effect of Row Spacing on the Growth and Yield of Peanut (Arachis hypogaea L.) Stands. International Journal of Agriculture, Forestry and Fisheries. Vol. 3, No. 1, 2015, pp. 7-11.

Dapaah, H.K, I. Mohammed, and R.T. Awuah, 2014. Growth Yield Performance of Groundnuts (Arachis hypogaea L.) in Response to Plant Density. International Journal of Plant and Soil Science 3(9):1069-1082, 2014.

Donald, C.M. 1963. Competition Among Crops and Pasture Plants. Advences in Agronomy, 15: 17-27.

Egli, D.B. 1988. Plant Density and Soybean Yield. Crop Science, 28:977-980

Gardner, F.P. and E.Q. Auma, 1989. Canopy Structure, Light Interception and Yield and Market Quality of Peanut Genotypes as Influenced by Planting Pattern and Planting Date. Field CropRes., 20: 13-29

Giayetto,O., G.A. Cerioni and W.E. Asnal. 1998. Effect of Sowing Spacing on Vegetative Growth, Dry Matter Production and Peanut Pod Yield. Peanut Science, 25: 86-92

Gulluoglu, L. 2011. Effects of Regulator Applications on Pod Yield and Some Agronomic Characters of Peanut in Mediterranean Region. Turk J Field Crops. 16(2):210-214

Gulluoglu, L., H. Bakal, B. Onat, C. Kurt, and H. Arioglu. 2016a. The Effect of Harvesting Dates on Yield and Some Agronomic and Quality Characteristics of Peanut Grown in Mediterranean Region (Turkey) Turk J Field Crops. 21(2): 224-232 (DOI:10.17557/ tifc.20186)

Gulluoglu, L., H. Bakal, B.Onat, A. El Sabagh, and H. Arioglu. 2016b. Characterization of Peanut (Arachis hypogeal L.) Seed Oil and Fatty Acids Composition Under Different Growing Season Under Mediterraean Environment. Journal of Experimental Biology and Agricultural Sciences. DOI:http://dx.doi.org/10.18006/2016, 4(5S):564-571

Gulluoglu, L., H. Bakal, H. Arioglu. 2016c. The Effects of Twin-row Planting Pattern and Plant Population on Seed Yield and Yield Components of Soybean at Late Double-Crop Planting in Cukurova Region. Turk J Field Crops. 21(1):59-65
Hosseini, N.M., R.H. Ellis and B. Yazdi-Samadi. 2001. Effects of Plant Population Density on Yield and Yield Components of Eight Isolines of cv. Clark (Glycine $\max$ L.). J. Agric. Sci. Technol., 3: 131-139.

Jaaffar, Z. and F.P. Gardner.1988. Canopy Development, Yield and Market Quality in Peanut as Affected by Genotype and Planting Pattern. CropSci. 28:299-305

Kadiroglu, A. 2012. Yerfistığı (Arachis hypogaea L.) Yetiştiriciliğinde Farklı Çeşitler ve Sıra Üzeri Mesafelere Gore Tek ve Çift Sıralı Ekim Yöntemlerinin Karşılaştırılması. Suleyman Demirel University, Institute of Science. $\mathrm{PhD}$ Thesis (in Turkish).

Kaushik, M.K. and A.K. Chaubey. 2000. Response of Rainy Season Bunch Groundnut (Arachis hypogeal L.) to Row Spacing and Seed Rate. Field Crops Research, 20: 407-410.

Konlan, S., J. Sarkodie-addo, E. Asareand and M.J. Kombiok. 2013. Groundnut (Arachis hypogaea L.) Varietal Response to Spacing in the Guinea Savanna Agro-Ecological Zone of Ghana. Growth and Yield. African J. of Agriculture Research, 8(22): 2769-2777.

Kvien, C.S. and C.L. Bergmark. 1987. Growth and Development of the Florunner Peanut Cultivar as Influenced by Population, Planting Date and Water Availability. Peanut Science: January 1987, Vol. 14, No. 1, pp. 11-16.

Lanier, J.E., D.L. Jordan, J.F. Spears, R. Wells, P.D. Johnson, J.S. Barnes, C.A. Hurt, R.L. Brandenburg and J.E. Bailey 2004. Peanut Response to Planting, Row Spacing, and Irrigation. Agronomy Journal, 96: 1066-1072.

Madkour, M.A., S.I. El- Mohandes, A.M.El-wakil 1992. Effect of Row-Spacing, Phosphorus, Potassium and Born Application on Some Peanut Cultivars. Egypt J. Agron., 17:127-140.

Nandanı, V.A., M.M. Modhawadia, J.C. Patel, S.G. Sadariaand, B.S. Patel 1993. Resonse of Rainy-season Bunch Groundnut to Row Spacing and Seed Rate. Indian Journal of Agronomy 37(3): 597-599.

Papastylianou, I., 1995. Spacing of Peanut Plants (Arachis hypogaea L.) Under Irrigation. Eur. J. Agron., 4: 101107.

Patil, H.M., P.T. Kolekar and B.T. Shete. 2007. Effect of Layouts and Spacing on Yield Quality of Bold Seeded Summer groundnut (Arachis hypogaea L.). Int'l J. Agric. Sci., 3 (2): 210-213.

Phillips, L.J., M.J.T. Norman. 1962. The Influence of Inter-Row Spacing and Plant Population on The Yield of Peanuts at Katherine, N.T. Australian Journal of Experimental Agriculture and Animal Husbandry, 2(4): $54-60$.

Prasad, P.V.V., P.Q. Craufurdand, R.J. Summerfield. 2000. Effect of High Air and Soil Temperature on Dry Matter Production, Pod Yield and Yield Components of Groundnut. Plant and Soil. 222: 231- 239.

Rasekh, H., J. Asghari, M.N. Safarzadeh Wishkai, S.L. Massoumi and R. Zakerinejad. 2010. Effect of Planting Pattern and Plant Density on Physiological Characteristics and Yield of Peanut (Arachis hypogeal 
L.) in Iran. Research J. of Biological Sciences., 5(8):542-547.

Schilling, R and R. Gibbons, 2002. Groundnut. The Tropical Agriculturist. Translated by Chater $\mathrm{S}$ and revised by Gibbons $R$, Nigam $S$, Chater $S$, Shambhakar DA, Dharne PK, Bahale TM, Anjali D, Surywanshi RT, Jadhav RB (2006). Assesment of Integrated Pest Management Modules in Groundnut on Farmers Fields. International Arachis Newsletter. 26:31-33.

Shiwlong, T., C. Tehming. 1996. Effects of Plant Density on Dry Matters Production and Partitionning in Groundnut. Bulletin of National Pingtung Polytechnic Instute (1996) 5 (1), 1-8. Department of PlantIndustry, National Pingtung Polytechnic Instute, Taiwan.

Silvertooth, J.C, K.L. Edmisten, W.H. McCarty. 1999. Production Practices. In: Cotton Origin, History, Technology and Production, eds C. W. Smith and J. T. Cothren, pp. 451-488. New York: John Wiley\&Sons
Sorensen, R.B, D. Sternitzke and M. Lamb. 2005. Row Orientation and Seeding Rate on Yield, Grade, and Disease Incidence of Peanut with Subsurface Drip Irrigation. Peanut Science, 28, 15-18.

Sternitzke, D.A, M.C. Lamb, J.I. Davidson, Jr.R.T. Barron and C.T. Bennet, 2000. Impact of Plant Spacing and Population on Yield for Single-Row Non irrigated Peanuts (Arachis hypogaea L.). Peanut Science: July 2000, Vol. 27, No. 2, pp. 52-56.

Tavora, F.A.J.F., P.F. Silva, O.D.I.F. Melo, B.J. Pitombeire and C.V.F. Neto. 2002. Yield Adaptability and Stability of Peanut Genotypes Estimated Under Different Environments. Ciência Agronmica. 33: 1014.

Wright, G.C. and M.J. Bell. 1992. Plant Population Studies on Peanut (Arachis hypogaea L.) in Subtropical Australia. 3. Growth and Water Use During a Termal Drought Stress. Aust J. Exp. Agriculture, 32: 197-203. 